\title{
Chemical HF Treatment for Rear Surface Passivation of Crystalline Silicon Solar Cells
}

\author{
Jeong-Ho Choi, Si-Cheol Roh, Jong-Dae Jung, and Hwa-II Seo ${ }^{+}$ \\ Department of Electrical \& Electronic \& Communication Engineering, Korea University of Technology and Education, \\ Cheonan 330-708, Korea
}

Received February 18, 2013; Revised March 18, 2013; Accepted May 21, 2013

P-type Si wafers were dipped in HF solution. The minority carrier lifetime (lifetime) increased after HF treatment due to the hydrogen termination effect. To investigate the film passivation effect, PECVD was used to deposit $\operatorname{SiN}_{\mathrm{x}}$ on both HF-treated and untreated wafers. $\mathrm{SiN}_{\mathrm{x}}$ generally helped to improve the lifetime. A thermal process at $850^{\circ} \mathrm{C}$ reduced the lifetime of all wafers because of the dehydrogenation at high temperature. However, the HF-treated wafers showed better lifetime than untreated wafers. PERCs both passivated and not passivated by HF treatment were fabricated on the rear side, and their characteristics were measured. The short-circuit current density and the open-circuit voltage were improved due to the effectively increased lifetime by HF treatment.

Keywords: Surface passivation, HF treatment, Minority carrier lifetime, PERC

\section{INTRODUCTION}

In the crystalline solar cell industry, improving efficiency is of vital importance. Highly efficient solar cells require minimizing the loss of the carrier generated by the irradiation of light. This has made research on improving the minority carrier lifetime (lifetime) by surface passivation especially valuable for manufacturing highly efficient solar cells. Because of the thinning of the wafer, the lifetime improvement is required both the front and back side of the wafer. The back surface recombination velocity (BSRV) and back surface reflectance (BSR) of screen-printed full-Al back-contact cells are not effective to inhibit the loss of cell efficiency caused by reduced wafer thickness [1-4]. In order to solve this problem, passivated solar cells on the back surface, such as passivated emitter and rear cells (PERCs), have been studied by many research groups $[3,4]$.

Decreasing defects of the wafer surface by passivation increases the lifetime. On a basic level, surface passivation can be divided into two methods. One is the chemical passivation

${ }^{\dagger}$ Author to whom all correspondence should be addressed:

E-mail: hiseo@koreatech.ac.kr

Copyright $@ 2013$ KIEEME. All rights reserved.

This is an open-access article distributed under the terms of the Creative Commons Attribution Non-Commercias

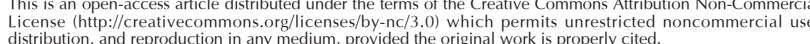

method using a solution containing hydrofluoric acid (HF), iodine, etc. The other is thin film passivation using silicon oxide $\left(\mathrm{SiO}_{2}\right)$, silicon nitride $\left(\mathrm{Si}_{3} \mathrm{~N}_{4}\right)$, etc. The HF treatment method has been found to be very useful for improving the lifetime through the hydrogen termination ( $\mathrm{H}$-termination) of the dangling bonds on the wafer surface [5-9].

The effect of HF treatment is widely known, but its application has not been sufficiently researched to improve the rear side passivation effect of PERCs. The chemical passivation by HF treatment was studied for the rear surface passivation of $p$ type Si-based crystalline solar cells. The HF treatment times and concentrations were adjusted to find the ideal combination. To confirm the change of the lifetime according to air exposure time, the HF-treated wafers were stored in air for a long time. A tube furnace was used to test the thermal stability of HF-treated wafers in the firing process. Finally, PERCs with HF treatment were fabricated. To compare the characteristics, untreated wafers were also prepared for each experiment.

\section{EXPERIMENTS}

\subsection{HF treatment}

Table 1 indicates the experimental order for testing the effect of HF treatment on the lifetime. 
P-type Cz (Czochralski) silicon solar wafers with $200 \mu \mathrm{m}$ thickness and $78 \mathrm{~mm} \times 78 \mathrm{~mm}$ area were used. Processes for saw damage removal (SDR) and RCA cleaning were performed to remove the damage, particles, and metal impurities on the wafer surface. SC-1 (an ammonia and peroxide mixture: APM, $\mathrm{NH}_{4} \mathrm{OH}: \mathrm{H}_{2} \mathrm{O}_{2}: \mathrm{H}_{2} \mathrm{O}=1: 2: 7$ ) and SC-2 (a hydrochloric acid and peroxide mixture: $\left.\mathrm{HPM}, \mathrm{HCl}: \mathrm{H}_{2} \mathrm{O}_{2}: \mathrm{H}_{2} \mathrm{O}=1: 2: 8\right)$ were used for 10 minutes at $80^{\circ} \mathrm{C}$. Diluted HF (DHF) was used for the HF treatment. The HF concentration ratio $\left(\mathrm{HF}: \mathrm{H}_{2} \mathrm{O}=1: 1, \mathrm{HF}: \mathrm{H}_{2} \mathrm{O}=1: 10\right.$, $\left.\mathrm{HF}: \mathrm{H}_{2} \mathrm{O}=1: 50\right)$ and treatment time (1 70s) were varied. The HFtreated wafers were exposed to air and the lifetime was measured. $\mathrm{SiN}_{\mathrm{x}}$ was deposited on HF-treated wafers to examine the effects on lifetime of film passivation. $\mathrm{SiN}_{\mathrm{x}}$ was deposited using plasma-enhanced chemical vapor deposition (PECVD). Silane $\left(\mathrm{SiH}_{4}\right)$, ammonia $\left(\mathrm{NH}_{3}\right)$, and nitrogen $\left(\mathrm{N}_{2}\right)$ gases were used, and the substrate temperature was $400^{\circ} \mathrm{C}$. The $\mathrm{NH}_{3} / \mathrm{SiH}_{4}$ ratio was 4 , and the RF power was $600 \mathrm{~W}$. The process pressure was 1 Torr. A tube furnace was used for heat treatment of the wafers at $850^{\circ} \mathrm{C}$. After the thermal process, the lifetime of HF-treated wafers was compared with that of wafers untreated with HF. The hydrogen content of the interface was measured according to the thermal process through secondary ion mass spectrometry (SIMS) analysis. The lifetime was measured using microwave photoconductive decay (MW-PCD) equipment.

\subsection{PERCs fabrication}

Table 2 shows the process order of PERC passivated by HF treatment on the rear surface.

P-type $\mathrm{Cz}$ silicon solar wafers with $200 \mu \mathrm{m}$ thickness and $78 \mathrm{~mm}$ $\times 78 \mathrm{~mm}$ area were used. A thick $\mathrm{SiN}_{\mathrm{x}}$ was deposited on the rear side by PECVD as a barrier to protect the surface during the surface texturing and phosphorus doping processes. A potassium hydroxide $(\mathrm{KOH})$ solution was used for the front side surface texturing for 30 minutes. The $\mathrm{n}^{+}$emitter layer was formed in thermal diffusion using the $\mathrm{POCl}_{3}$ tube furnace. A thick $\mathrm{SiN}_{\mathrm{x}}$ on the rear side was etched by plasma, and then a $100 \mathrm{~nm} \mathrm{SiO}{ }_{2}$ was deposited on the front side of the wafer to protect the overall pyramid structure from SDR and RCA cleaning for the rear side. DHF (HF: $\mathrm{H}_{2} \mathrm{O}=1: 10$ ) solution was used to remove the overall phosphorus silicate glass (PSG) film and to reduce defects such as dangling bonds on the wafer surface. A $100 \mathrm{~nm} \mathrm{SiN}_{\mathrm{x}}$ was deposited as an anti-reflection coating (ARC) and for the rear side passivation. The rear side passivation film was locally opened for the electrode contact by a $532 \mathrm{~nm}$ laser. Metallization was conducted using screen printing method. Ag paste was used as a front electrode, and $\mathrm{Al}$ paste was used as a rear electrode. A firing process was applied using a belt furnace, and then edge isolation was carried out using a $532 \mathrm{~nm}$ laser equipment. Finally, the characteristics of the fabricated PERCs were evaluated.

\section{RESULTS AND DISCUSSIONS}

\subsection{The lifetime according to HF treatment times and concentrations}

Figure 1 indicates the lifetime of HF-treated wafers according to the HF treatment times and concentrations. The lifetime of all wafers was increased by HF treatment. During the first several seconds, the lifetime of wafers increased randomly. However, regardless of the HF concentration, the lifetime of wafers became equal to about $18 \mu$ s after about 50 seconds. From the results, it is anticipated that the chemical native $\mathrm{SiO}_{2}$ grown in RCA cleaning is etched by HF treatment during the first several seconds. Varied increase rates in the lifetime are shown because each wafer has a
Table 1. Process of experiment.

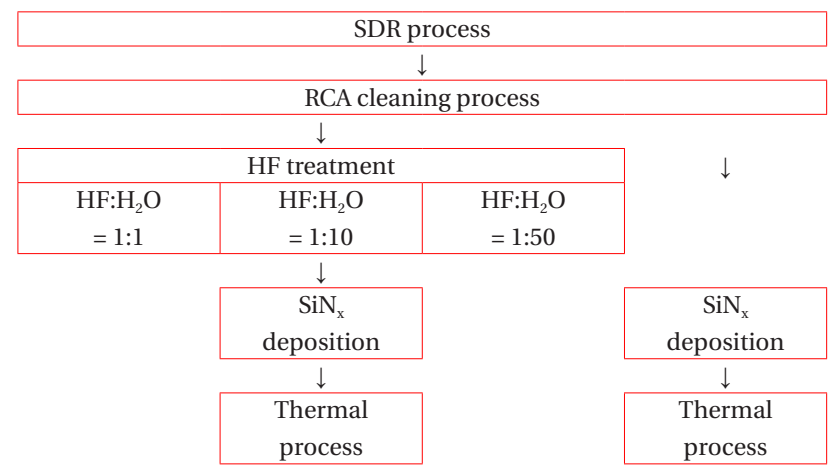

Table 2. Fabrication process of PERC.

\begin{tabular}{l}
\hline Rear barrier deposition \\
$\downarrow$ \\
\hline Pre-cleaning \& Hot D.I water treatment \\
$\downarrow$ \\
\hline Surface texturing \\
$\downarrow$ \\
\hline HPM \& HF treatment \\
\hline$\downarrow$ \\
\hline Diffusion \& PSG removal \\
\hline$\downarrow$ \\
\hline Rear barrier etching \\
$\downarrow$ \\
\hline Front barrier deposition \\
$\downarrow$ \\
\hline Rear side SDR \& RCA cleaning \\
$\downarrow$ \\
\hline Front barrier etching \& HF treatment \\
$\downarrow$ \\
\hline ARC \& rear passivation film deposition (SiN S $\left._{\mathrm{x}}\right)$ \\
$\downarrow$ \\
\hline Local back contact \\
$\downarrow$ \\
\hline Metallization \\
$\downarrow$ \\
\hline Firing \\
\hline \\
\hline
\end{tabular}

different thickness of the native $\mathrm{SiO}_{2}$ grown in RCA cleaning [5-8]. Furthermore, the three DHF solutions have different expiration dates and HF concentrations. However, the lifetime of all wafers levels out after about 50 seconds without the HF concentration, because the $\mathrm{H}$-termination that negates the defects reaches a saturation point. Therefore, in all subsequent experiments, DHF ( $\mathrm{HF}: \mathrm{H}_{2} \mathrm{O}=1: 10$ ) solution was applied for 50 seconds.

\subsection{The lifetime according to air exposure time}

Figure 2 indicates the lifetime of HF-treated wafers according to air exposure time in a clean room atmosphere. The HF ( $\mathrm{HF}: \mathrm{H}_{2} \mathrm{O}=1: 10$ ) treatment time was varied.

For the first 24 hours, the lifetime of all wafers decreased differently according to the HF treatment times, except for the untreated wafer. After 70 hours of exposure, the lifetime of all wafers was fixed at about $2.5 \mu \mathrm{s}$. It is thought that the lifetime decreases over about 10 hours because of rapid native $\mathrm{SiO}_{2}$ growth by composite effects including dehydrogenation, Si density of the surface, adsorbents like carbon and oxygen, and dangling bonds, etc. After about 10 hours, it is considered to grow the 


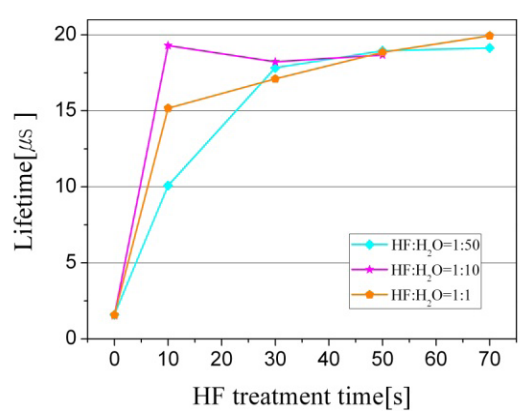

Fig. 1. The lifetime at varied HF treatment times and concentrations.

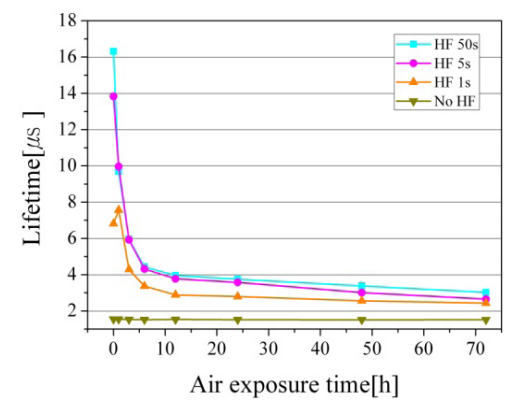

Fig. 2. The lifetime of wafers with various $\mathrm{HF}\left(\mathrm{HF}: \mathrm{H}_{2} \mathrm{O}=1: 10\right)$ treatment times according to air exposure time.

layer by layer [5-9].

\subsection{Effects of the $\mathrm{SiN}_{\mathrm{x}}$ deposition on the lifetime}

Figure 3 shows the lifetime of wafers on which a $100 \mathrm{~nm} \mathrm{SiN}$ was deposited after $\mathrm{HF}\left(\mathrm{HF}: \mathrm{H}_{2} \mathrm{O}=1: 10,50\right)$ treatment, according to air exposure time in the clean room atmosphere.

The lifetime of wafers without $\operatorname{SiN}_{\mathrm{x}}$ decreased to about $4 \mu \mathrm{s}$ in 24 hours. However, the lifetime of wafers with $\mathrm{SiN}_{\mathrm{x}}$ was reduced somewhat compared to wafers without $\mathrm{SiN}_{\mathrm{x}}$. From the figure, it is considered that when $\mathrm{SiN}_{\mathrm{x}}$ is deposited on HF-treated wafers, the wafers are protected against the aforementioned composite effects.

Figure 4 indicates the lifetime of wafers with various HF (HF: $\mathrm{H}_{2} \mathrm{O}=1: 10$ ) treatment times according to the $100 \mathrm{~nm} \mathrm{SiN} \mathrm{N}_{\mathrm{x}}$ deposition. The HF treatment times were adjusted to $0,1,5,10,50$ seconds.

With the $\mathrm{SiN}_{\mathrm{x}}$ deposition, the lifetime of wafers HF-treated for a short time increased more than those of wafers HF-treated for a long time. However, the lifetime of wafers HF-treated for 50 seconds decreased from $20.41 \mu$ s to $16.68 \mu$ s due to the $\operatorname{SiN}_{x}$ deposition. It is expected that when the wafers are shortly treated by HF, the remaining defects are reduced by the passivation effect of the $\mathrm{SiN}_{\mathrm{x}}$ deposition [10,11]. However, when the H-termination becomes saturated with HF treatment for 50 seconds, the stress of $\mathrm{SiN}_{\mathrm{x}}$ deposited by PECVD can reduce the lifetime [12]. Nevertheless, it is clear that the lifetime of wafers HF-treated for 50 seconds with the $\operatorname{SiN}_{\mathrm{x}}$ deposition achieves the best result.

Two passivation effects of $\mathrm{SiN}_{\mathrm{x}}$ on p-type wafers are expected: the reduction of the dangling bonds at the interface by atomic hydrogen, and the field-effect passivation caused by a high density of fixed positive charges. The stress effect that is detrimental to the electrical and optical performance of devices is also considered. It is thought that when the lifetime of wafers treated with HF for a short time is very low, the passivation effects of $\mathrm{SiN}_{\mathrm{x}}$ are more pronounced than the stress effect. However, when

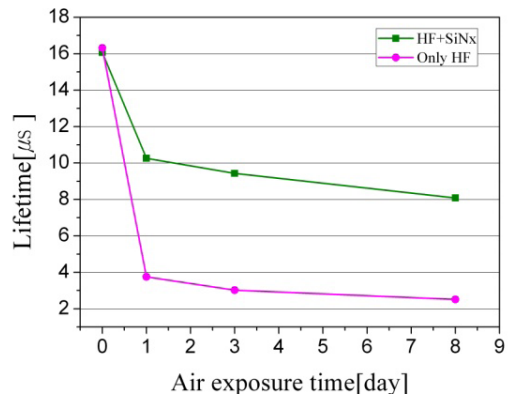

Fig. 3. The lifetime of HF-treated wafers according to air exposure time. Before exposure, a $100 \mathrm{~nm} \mathrm{SiN}_{\mathrm{x}}$ deposited.

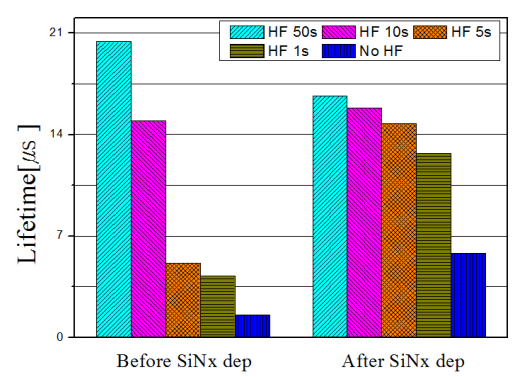

Fig. 4. The lifetime of HF-treated wafers according to the $\operatorname{SiN}_{\mathrm{x}}$ deposition. The HF treatment times were varied.

the lifetime of wafers is very high, the stress effect is much higher compared with the passivation effects, which decreases the lifetime.

\subsection{The lifetime according to the thermal process}

Figure 5 indicates the lifetime of HF-treated wafers according to the thermal process at $850^{\circ} \mathrm{C}$. Before the thermal process, the $\mathrm{HF}$ treatment $\left(\mathrm{HF}: \mathrm{H}_{2} \mathrm{O}=1: 10,50 \mathrm{~s}\right)$ was applied and a $100 \mathrm{~nm} \mathrm{SiN}$ was deposited.

The lifetime of all wafers decreased after the thermal process.

Figure 6 shows the hydrogen content of HF-treated wafers according to the thermal process at $850^{\circ} \mathrm{C}$. A $100 \mathrm{~nm} \mathrm{SiN}$ was deposited before the thermal process. The dehydrogenation in the interface between the wafer and $\mathrm{SiN}_{\mathrm{x}}$ was investigated after the thermal process.

It is considered that the lifetime is reduced from $16.68 \mu$ s to 7.61 $\mu$ s in Fig. 5 because the hydrogen atoms probably effuse from the wafer.

Figure 7 signifies the hydrogen content of HF-treated wafer according to the thermal process at $850^{\circ} \mathrm{C}$. A $100 \mathrm{~nm} \mathrm{SiN}$ was deposited before the thermal process. To compare the hydrogen content after the thermal process, an untreated wafer was prepared. The hydrogen content in the interface (80-90 nm) of HFtreated wafer was higher than that of HF-untreated wafer after the thermal process.

From the results, it is anticipated that the lifetime of HFtreated wafer in Fig. 5 is higher than that of HF-untreated wafer, because the greater amount of hydrogen atoms in the interface led to a reduction in defects. Therefore, the lifetime of HF-treated wafers are found to be higher than those of HF-untreated wafers.

Figure 8 indicates the lifetime after the thermal process at $850^{\circ} \mathrm{C}$ according to air exposure time. The lifetime of all wafers were reduced. The lifetime of the HF-treated wafers were reduced to about $6 \mu$ s after 85 days. However, the lifetime was still 


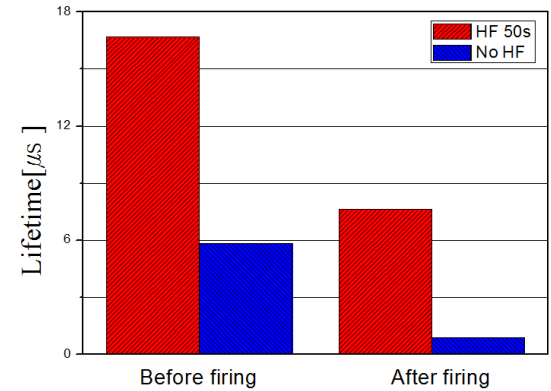

Fig. 5. The lifetime after the thermal process at $850^{\circ} \mathrm{C}$. HF treatment was applied and a $100 \mathrm{~nm} \mathrm{SiN}$ was deposited before the thermal process.

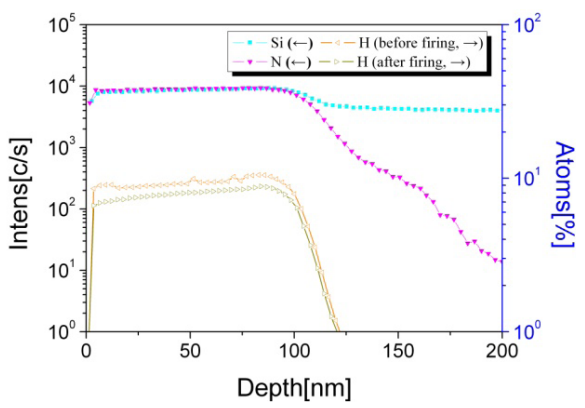

Fig. 6 . The hydrogen content SIMS profile after thermal process at $850^{\circ} \mathrm{C}$. A $100 \mathrm{~nm} \mathrm{SiN}{ }_{\mathrm{x}}$ was deposited before the thermal process.

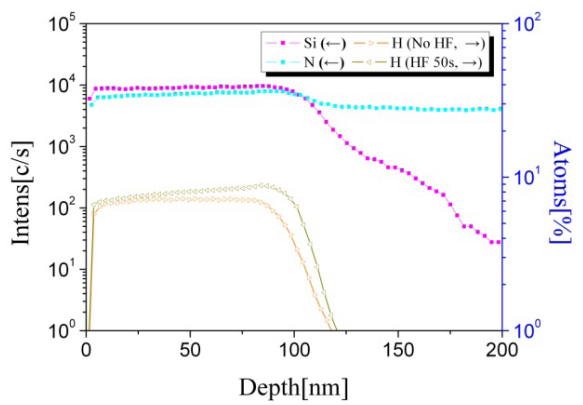

Fig. 7 . The hydrogen content SIMS profile after the thermal process at $850^{\circ} \mathrm{C}$. HF treatment was applied and a $100 \mathrm{~nm} \mathrm{SiN}_{\mathrm{x}}$ was deposited before the thermal process.

very higher than those of HF-untreated wafers.

\subsection{PERCs characteristics according to HF treatment}

Table 3 shows the characteristics of fabricated PERCs according to HF treatment. Figure 9 shows the I-V characteristic curve.

The efficiency of HF-treated PERCs was $13.22 \%$ on average, and the efficiency of untreated PERCs was $12.82 \%$ on average. The short-circuit current density $\left(\mathrm{J}_{\mathrm{sc}}\right)$ and the open circuit voltage $\left(\mathrm{V}_{\mathrm{oc}}\right)$ of HF-treated PERCs was higher at $1.57 \mathrm{~mA} / \mathrm{cm}^{2}$ and $5 \mathrm{mV}$ on average than those of PERCs not treated with HF. It is thought that $\mathrm{J}_{\mathrm{sc}}$ and $\mathrm{V}_{\mathrm{oc}}$ are increased because of the enhanced collection probability of the carriers and the decreased recombination of electron hole pairs (EHPs) in the interface between the rear surface and $\mathrm{SiN}_{\mathrm{x}}$ by the rear side passivation with HF treatment, which increased efficiency $[1,2]$. The efficiency of PERCs passiv-

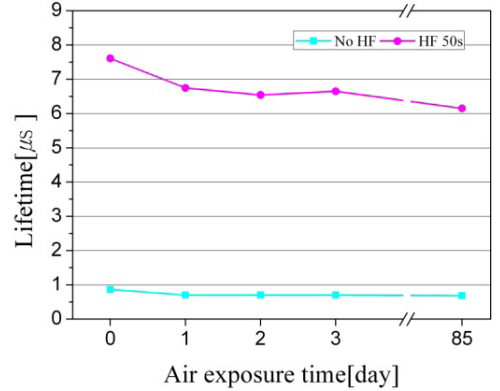

Fig. 8. The lifetime after the thermal process at $850^{\circ} \mathrm{C}$ according to air exposure time. HF treatment was applied and a $100 \mathrm{~nm} \mathrm{SiN} \mathrm{S}_{\mathrm{x}}$ was deposited before the thermal process.

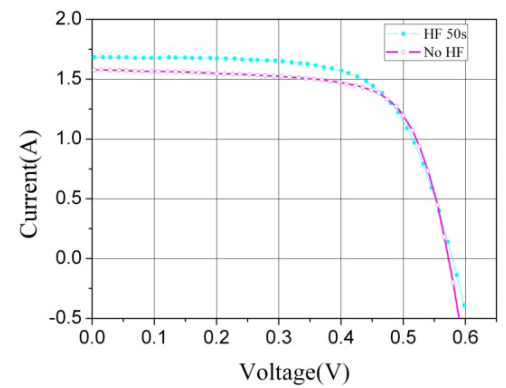

Fig. 9. The I-V curve of fabricated PERCs according to HF treatment.

Table 3. PERC characteristics.

\begin{tabular}{ccccc}
\hline & $\begin{array}{c}\text { Voc } \\
(\mathrm{mV})\end{array}$ & $\begin{array}{c}\text { Jsc } \\
(\mathrm{mA} / \mathrm{cm} 2)\end{array}$ & $\begin{array}{c}\text { FF } \\
(\%)\end{array}$ & $\begin{array}{c}\text { Eff. } \\
(\%)\end{array}$ \\
\hline $\begin{array}{c}\text { Average } \\
\text { HF 50s }\end{array}$ & 578 & 33.64 & 68.01 & 13.22 \\
\hline $\begin{array}{c}\text { Max. } \\
\text { HF 50s }\end{array}$ & 579 & 34.33 & 67.04 & 13.33 \\
\hline $\begin{array}{c}\text { Average } \\
\text { No HF }\end{array}$ & 573 & 69.72 & 69.72 & 12.82 \\
\hline $\begin{array}{c}\text { Max. } \\
\text { No HF }\end{array}$ & 573 & 32.17 & 70.56 & 13.00 \\
\hline
\end{tabular}

ated by HF treatment is higher than that of the non-passivated PERCs. However, the efficiencies of PERCs were low in general because the PERC fabrication process was very complicated. The contact area on the rear side was just $1 \%$, and the firing temperature and speed were set for standard solar cell fabrication. Also, all wafers were exposed many times to air, because the fabrication process was very complicated. Therefore, it is considered that the efficiency will be improved by greater optimization of the PERC fabrication process.

\section{CONCLUSIONS}

This research attempted to identify improvements in crystalline silicon solar cell efficiency by improving the rear side passivation characteristics using a chemical HF treatment method on p-type silicon wafers. PERCs were fabricated with HF treatment on the rear side of the wafer to measure the efficiency.

After HF treatment of 50 seconds, the lifetime had a fixed value of about $18 \mu$ s irrespective of the HF concentration. When $\operatorname{SiN}_{x}$ was deposited on the wafers, the decrease rate of the lifetimes ac- 
cording to air exposure time was reduced because $\mathrm{SiN}_{\mathrm{x}}$ protected the wafers from the composite effects including the native $\mathrm{SiO}_{2}$ growth, dehydrogenation, Si density of the surface, adsorbents like carbon and oxygen, and dangling bonds. In addition, after the thermal process at $850^{\circ} \mathrm{C}$ for about 5 seconds, the lifetime of wafers with $\mathrm{HF}$ treatment and the $\mathrm{SiN}_{\mathrm{x}}$ deposition was reduced from $16.68 \mu$ s to $7.6 \mu \mathrm{s}$. However, the lifetime of HF-treated wafers was still high compared with those of HF-untreated wafers after the thermal process, because of the greater abundance of hydrogen atoms in the interface.

The efficiency of PERCs passivated on the rear surface by HF treatment was $13.22 \%$, higher than the $12.82 \%$ of the nonpassivated PERCs, because the carrier collection probability that was increased by HF treatment also made $\mathrm{J}_{\mathrm{sc}}$ and $\mathrm{V}_{\mathrm{oc}}$ increase. However, the characteristics of solar cells were poor because all of the fabrication processes were not optimized. So, it is considered that the efficiency will be improved by greater optimization of the PERC fabrication process.

\section{REFERENCES}

[1] K. H. Kim and J. S. Yi, Introduction to Solar Cell Production, (Dooyangsa, Seoul, 2009).

[2] J. H. Lee, D. G. Lim and J. S. Yi, Principle of solar cell, (Hongrung publishing company, Seoul, 2005).

[3] D. Y. Lee, H. H. Lee, J. Y. Ahn, H. J. Park, J. H. Kim, H. J. Kwon and J. W. Jeong, A new back surface passivation stack for thin crystalline silicon solar cells with screen-printed back contacts, Solar Energy Materials \& Solar Cells 95, p. 26-29 (2011) [DOI: http://dx.doi.org/10.1016/j.solmat.2010.05.004].

[4] Ryo Ozaki, Hidenori Yashiki, Ryusuke Imai, Sachiyo Ooka, Yuji Kurimoto, Ichiro Yamasaki, Yoshihiro Yamamoto and Tatsuo Saga, Fabrication of SiN rear passivated thin multi-crystalline silicon solar cell with $30 \mu \mathrm{m}$-wide screen-printed front electrode, $24^{\text {th }}$ EUPVSEC, p. 1175-1178 (2009).

[5] H. Angermann, W. Henrion, M. Rebien and A. Röseler, Wetchemical preparation and spectroscopic characterization of Si interfaces, Appl. Surf. Sci. 235, p. 322-339 (2004) [DOI: http:// dx.doi.org/10.1016/j.apsusc.2004.05.105].

[6] H. Angermann, W. Henrion, M. Rebien and A. Röseler, Wetchemical passivation and characterization of silicon interfaces for solar cell applications, Solar Energy Mater. \& Solar Cells 83, p. 331-346 (2004) [DOI: http://dx.doi.org/10.1016/ j.solmat.2004.01.031].

[7] H. Angermann, Passivation of structured p-type silicon interfaces: Effect of surface morphology and wet-chemical pre- treatment, Appl. Surf. Sci. 254, p. 8067-8074 (2008) [DOI: http:// dx.doi.org/10.1016/j.apsusc.2008.03.022].

[8] A. Laades, J. Brauer, U. Stürzebecher, K. Neckermann, K. Klimm, M. Blech, K. Lauer, A. Lawerenz and H. Angermann, Wet-chemical treatment of solar grade CZ silicon prior to surface passivation, $24^{\text {th }}$ EUPVSEC, p. 1640-1644 (2009).

[9] S. G. Kwon, W. Y. Jeong and J. H. Wang, No damage and high selective cleaning technology for very large scale integrated circuit, ITFIND, p. 1-33 (2004).

[10] Florence W. Chen, Tsu-Tsung A. Li and Jeffrey E. Cotter, PECVD silicon nitride surface passivation for high-efficiency n-type silicon solar cells, IEEE $4^{\text {th }}$ WCPEC 1 , p. 1020-1023 (2006).

[11] S. Dauwe, L. Mittelstädt, A. Metz and R. Hezel Experimental Evidence of Parasitic Shunting in Silicon Nitride Rear Surface Passivated Solar Cells, Prog. Photovolt: Res. Appl., p. 271-278 (2002).

[12] K. D. Mackenzie, D. J. Johnson, M. W. DeVre, R. J. Westerman and B. H. Reelfs, Stress control of Si-based PECVD dielectrics, $207^{\text {th }}$ Electrochemical Society Meeting, PV2005-01, p. $148-159$ (2005).

[13] Korea University of Technology and Education $E^{2}$-Semicinductor Equipment HRD Center, The study of manufacturing process for the high efficiency screen printed crystalline solar cell (Korea University of Technology and Education, Cheonan, 2010)

[14] J. H. Choi, S. C. Roh, D. Y. Yu, Z. H. Li, Y. C. Kim and H. I. Seo, A Study on HF Chemical Passivation for Crystalline Silicon Solar Cell Application, J. the Semiconductor \& Display Equipment Technology 10(1), p. 51-55 (2011).

[15] G. Agostinelli, P. Choulat, H. F. W. Dekkers, E. Vermarien and G. Beaucarne, Rear surface passivation for industrial solar cells on thin substrates, IEEE 4th WCPEC 1, p. 1004-1007 (2006).

[16] S. Dauwe, L. Mittelstad, A. Metz, J. Schmidt and R. Hezel, Lowtemperature rear surface passivation schemes for $>20 \%$ efficient silicon solar cells, 3rd World Conference on Photovoltaic Energy Conversion, p. 1395-1398 (2003).

[17] J. Dupuis, E. Fourmond, O. Nichiporuk, F. Gibaja and M. Lemiti, Rear passivation schemes for industrial silicon solar cells, $23^{\text {rd }}$ EUPVSEC, p. 1633-1636 (2008).

[18] F. Llopis and I. Tobías, The role of rear surface in thin silicon solar cells, Solar Energy Materials \& Solar Cells 87, p. 481-492 (2005) [DOI: http://dx.doi.org/10.1016/j.solmat.2004.06.015].

[19] P. Ortega, A. Orpella, G. López, I. Martín, C. Voz, R. Alcubilla, I. Sánchez-Aniorte, M. Colina, F. Perales and C. Molpeceres, Optimization of the rear point contact scheme of crystalline silicon solar cells using laser-fired contacts, $25^{\text {th }}$ EUPVSEC, p. 21262129 (2010). 